UDC 632.08

\title{
ENERGY EFFICIENCY RESEARCH OF FERMENTATION MEDIUM AGITATION IN MANUFACTURING OF MICROBIOLOGICAL PLANT PROTECTION PRODUCTS
}

\author{
V. P. Yaroshevsky \\ Engineering and Technological Institute «Biotechnica» NAAS, Ukraine \\ 67667, Odesa Region, Biliaivka District, Hlibodarske, Maiatska dor., 26, Ukraine
}

E-mail:wladscience@gmail.com

Received December 28, 2018 / Received March 29, 2019 / Accepted July 19, 2019

\begin{abstract}
Aim. The main aim of the research was to compare different methods of fermentation medium energy efficiency agitation. Methods. The analysis of mass transfer processes in fermenters using different methods of agitation was made. Experimental determination of energy consumption for medium agitation while using a mechanical agitator and an external circulation loop was realized. Estimation of energy efficiency indices. Results. It was determined that energy efficiency of agitation by circulation during the cycle of bacterial preparation Planriz BT (Biotechnica) exceeded mechanical agitation 1.3 times in case of aeration, and 2.6 times in the non-aeration mode. Conclusions. The method of agitation by circulation of fermentation medium using an external loop is more energy-efficient compared to mechanical agitation even in the case of using a slow-speed agitator.
\end{abstract}

Keywords: energy efficiency, fermentation medium, agitation, intensity, circulation, fermenter.

DOI: https://doi.org/10.15407/agrisp6.02.076

\section{INTRODUCTION}

Energy efficiency improvement of industrial production is a global tendency. However, practical implementation of the task of ensuring a high level of energy efficiency meets some difficulties, as specific methods of technological processes optimization are notable only for some industries (construction, power economy, etc.). Usually energy efficiency improvement of industries in other spheres is based on decreasing energy losses while the implementation of technological processes and energy losses reduction for non-industrial needs [1].

The study is aimed at solving the problem of technological processes energy efficiency improvement of microbiological preparations manufacturing. As there is no common optimization methods for industrial microbiology, the engineering solutions, aimed at reducing the level of power consumption, are mainly used to enhance energy efficiency of processes. However, this approach has some limits: it does not provide for the comparison of energy efficiency of implementing the same process with using of principally different technological methods [2].

(c) V. P. YAROSHEVSKY, 2019
For instance, the agitation of fermentation medium during submerged cultivation of microorganisms may involve the application of several methods: mechanical agitation, barbotage, agitation using external or internal circulation loop, etc. Each method envisages the presence of principally different equipment, the efficiency of which is not determined by power consumption only. The selection of the most energy-efficient method of agitation should consider quantitative and qualitative characteristics of the process. Previous analytical studies [2] demonstrated that medium's circulation around the external loop with the use of a pump is the most energy-efficient agitation technique [3]. Experimental studies are required to substantiate this conclusion.

Ensuring of a proper level of microbiological preparations' manufacturing energy efficiency is mainly possible via power consumption reduction by usage of technological processes automation and non-technological origin power consumption decrease (heating of premises, illumination of working places, etc.) [4].

Among the studies, dedicated to the energy efficiency of equipment in biotechnology, it is noteworthy the paper [5]. 
The authors presented the results of energy efficiency comparison of the microboilogical preparations cultivation methods using bioreactors of different design, obtained via computer modeling of physical and biological processes. It is not deemed possible to determine energy efficiency of specific technological processes of fermentation stage (agitation, aeration, etc.) based on these data.

The issue of energy efficiency improvement of fermentation medium agitation is not sufficiently described in scientific literature. Current studies are mainly related to the most common mechanical method of agitation [6-8]. Energy efficiency improvement is envisaged due to the power consumption reduction by the optimization of fermenter's design $[6,7]$ or maintenance of experimentally determined optimal conditions for agitators of such type [8].

Designing of external circulation loop is mainly aimed at solving specific technological tasks $[9,10]$, for instance, they are used for simultaneous implementation of several technological processes [11, 12]. However, no studies have been found regarding the application of external circulation loops with pumping as engineering solutions used for energy efficiency improvement of fermentation medium agitation.

Therefore, references analysis demonstrates that studies devoted to energy efficiency improvement of technological processes, in particular, agitation of fermentation medium, are isolated and limited by the improvement of specific devices. So the comparison of energy efficiency of fermentation medium's agitation different methods in manufacturing of microbiological plant protection products was the aim of this research.

Previous studies of different methods of fermentation medium agitation [2] showed that the most energy efficient method was agitation by using an external circulation loop. This article was aimed at analytical and experimental substantiation of previously obtained results.

\section{MATERIALS AND METHODS}

Two methods of fermentation medium agitation were explored: mechanical method and agitation using circulation. The mechanical agitation was realized by the slow-speed agitator. The agitation by circulation was implemented using the external circulation loop with pumping.

There were analytical and experimental parts in the study. The first part was aimed at comparing mass transfer processes based on the hydraulic schemes analysis of the process, and the second one - experimental determination of power consumption. The agitation energy efficiency was calculated as reciprocal specific power consumption per unit of fermentation medium volume [2].

The analytical part of the study included:

- determination of flows distribution specificities in experimental equipment based on reference data;

- determination of mass transfer intensity using Reynolds number based on technical characteristics of the

agitator and circulation pump with the consideration of indicated flows distribution specificities;

- comparison of the obtained processes mass transfer characteristics.

The experimental part of the study included physical modeling of mass transfer in fermenters with the determination of electric energy consumption. The schemes of experimental equipment are presented in Fig. 1 and 2.

The mechanical agitation of fermentation medium was simulated at experimental setup No. 1 (Fig. 1). The equipment consists of a thin-walled fermenter of FTU type 1 with the working volume of 701 , equipped with the mechanical agitator 2 with the consumption of $N=0.036 \mathrm{~kW}$ and the rotation frequency of $50 \mathrm{rpm}$. The medium aeration was realized by barbotage. Pressured air was supplied by compressor 4 to the fermenter bottom through a hollow agitator shaft 3 .

The agitation by circulation was simulated at experimental setup No. 2 (Fig. 2), based on the use

of a thin-walled fermenter of FTU type 1 with the working volume of 701 . The fermenter was equipped with the external circulation loop 3, the centrifugal pump Aquario AC 254-180 2 with the nominal electric power of $0.05 \mathrm{~kW}$ and three wheel velocities $(n=1710 \ldots 2850 \mathrm{rpm})$. The aeration of the medium was performed by jet mixer 4 . For this purpose, pressured air was supplied through the nozzle into the cocurrent flow of the medium.

The pressured air was supplied to both experimental equipment sets using a piston-type compressor $\mathrm{ABAC}$ FC2/50 at 1.5 bar at the reducer outlet. The evaluation of power consumption in the experiments was conducted using an electric meter SA4U-I672M with the accuracy class 2 . It should be noted that experimental setups were built on the basis of the equipment of prototype fermentation complex KFM-420 [13]. The complex is a technological line for microbial pesti- 


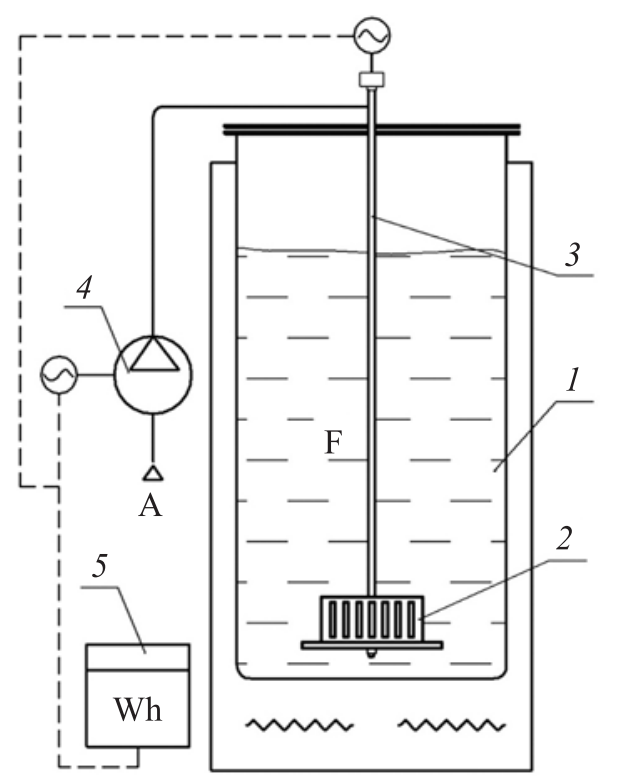

Fig. 1. The experimental setup No. 1: 1 - thin-walled fermenter; 2 - turbine agitator; 3 - hollow shaft of agitator; 4 - air compressor; 5 - electric meter; $\mathrm{A}$ - air; F - fermentation medium

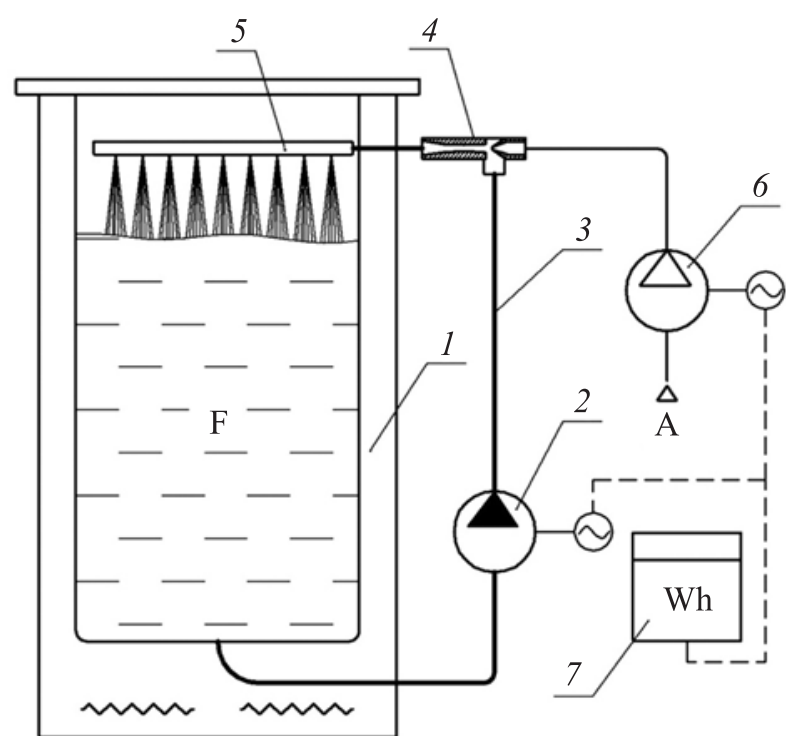

Fig. 2. The experimental setup No. 2: 1 - thin-walled fermenter; 2 - circulation pump; 3 - external circulation loop; 4 - jet mixer; 5 - medium spray device; 6 - air compressor; 7 - electric meter; A - air; F - fermentation medium

cides production with the productivity of $140 \ldots 4201 /$ cycle. It consists of four automated modules, designed for autonomous implementation of technological processes stages (preparation and sterilization of nutrient medium, purification of water and air, microorganism cultivation). The experimental setups were switched to the fermentation module, that consisted of fermenters of FTU type with the volume of 1001 each.
As bacterial preparations are less sensitive to the mechanical stress, resulting from the medium transfer through the blade wheel of the pump, mass transfer processes were modeled for fermentation medium to cultivate the bacterial preparation Planriz BT. The weight fraction of dry components in the medium did not exceed $5 \%$. Thus, its viscosity - one of the key characteristics, impacting mass transfer processes, was almost not different from water viscosity in experiments.

The general experiments technique was: 701 of the medium were supplied to the fermenter, and then process of agitation with one of the methods was started. The agitation lasted for the estimated time. The readings of the electric meter were registered prior to and after the agitation, and their difference demonstrated power consumption for the process. Energy consumption was determined for each agitation method in two modes: with and without medium aeration.

The results processing technique consisted of the determination of agitation power consumption by the readings of the electric meter and further statistical data processing by means of MS Excel [14]. Power consumption, obtained in the experiment, and experiment duration were used to calculate agitation electric energy consumption for the Planriz BT cultivation cycle, which lasted for $24 \mathrm{~h}$. Then energy efficiency was found.

\section{RESULTS AND DISCUSSION}

1. The analysis of mass transfer processes. Mass transfer processes analysis was used for meaningful comparison of the fermentation medium agitation methods, realized by principally different hydraulic schemes. This necessity arises from the general concept of energy efficiency, which may be formulated as follows: energy efficiency of the process is a ratio of a beneficial effect and energy consumption needed for its obtaining [15]. Thus, meaningful comparison of different methods of the technological process implementing is possible only when beneficial effects, obtained by these methods, are comparable.

There was fermentation medium volume selected as beneficial effect in determining energy efficiency of agitation [2]. Therefore, medium volume should have the same properties for both agitation methods for the comparison. This result could be obtained by ensuring similar mass transfer characteristics.

Flows distribution characteristics were investigated during the analytical study. These characteristics were 
taken into account in mass transfer intensity estimation and further comparison of the processes.

Flows distribution schemes, formed in the fermenter during mechanical agitation, were studied rather thoroughly [16-19]. There are two types of fluid flow patterns inside the fermenter created by the impeller: the main radial flow, which is formed perpendicularly to the agitator axis, and the secondary axial flow (pumping), which is formed when fluid circulates along the axis [16]. The intensity of these flow patterns depends on the impeller type and velocity of its rotation $[17,18]$.

The analysis demonstrated that low speed of the impeller $(50 \mathrm{rpm})$ led to low intensity of both main and secondary flows. The most intensive medium movement occurred in the area, close to the impeller, i.e. in this case it covered bottom layers of the medium. The surface layers, located far from the impeller, moved more slowly. The axial flow is not intensive, so surface and bottom layers'mixing is insignificant. Consequently, there are two hydrodynamic zones inside the fermenter created by the slow-speed agitator: intensive medium movement zone, located near the bottom, and slow medium movement zone located near the surface (Fig. 3,a).

In the case of agitation by circulation the main flow is pumping. It is formed along the fermenter axis, as bottom layers are pumped through the external loop and jetting at the surface of the medium. However, medium movement conditions in the fermenter and in the circulation loop differ considerably because of a big difference in the flows cross-section. The analysis shows that slow gradual movement of the medium takes place inside the fermenter and intensive movement occurs in the circulation loop. Thus, in the case of agitation by circulation two zonesalso existed: intensive medium movement zone, located in the external circulation loop, and slow medium movement zone located inside the fermenter (Fig. 3, $b$ ).

Therefore, regardless of different principles of the process organization, qualitative agitation characteristics are similar for both methods: there are two hydrodynamic zones with different mass transfer intensity in setups. There was detailed analysis of medium agitation intensity in these zones for each setup.

The agitation intensity in fermenters and bioreactors is generally viewed in terms of fluid dynamic dimensionless quantity numbers, such as Reynolds number. However, the equations used for calculations of me-

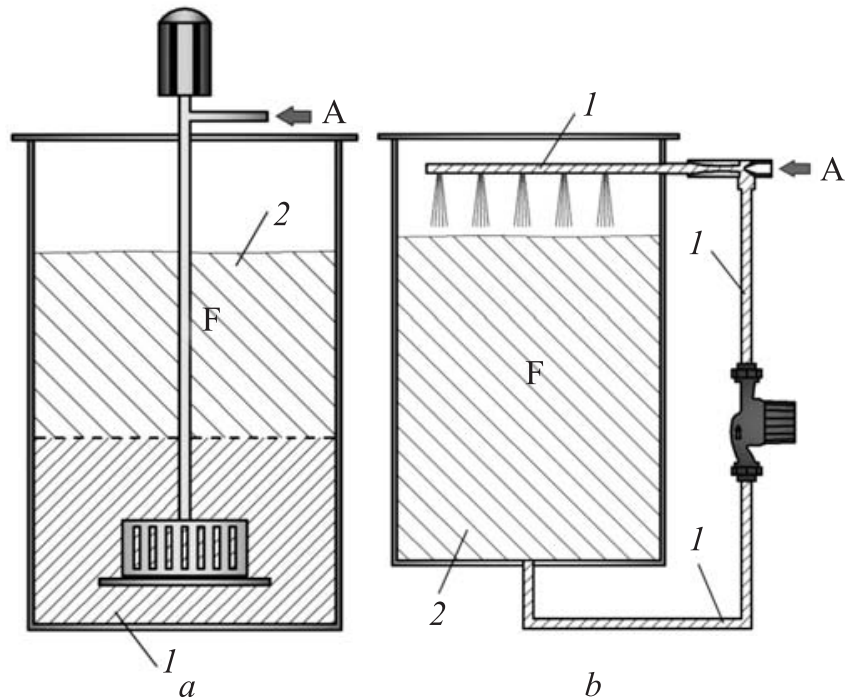

Fig. 3. Zones of vigorous mixing and slow movement of the medium that were brought about as a result of mechanical agitation $-a$; agitation by circulation $-b .1-$ zone of vigorous medium mixing; 2 - zone of slow medium movement; A - pressured air; F - fermentation medium

chanical agitation and agitation by circulation are different $[16,18]$ :

$$
\begin{aligned}
& \operatorname{Re}=\frac{w \cdot d \cdot \rho}{\mu} \\
& \operatorname{Re}^{*}=\frac{n \cdot D^{2} \cdot \rho}{\mu}
\end{aligned}
$$

where $\mathrm{Re}, \mathrm{Re}^{*}$ - Reynolds number for fluid flows in channels of different geometry and for tanks with mechanical agitation; $d$-diameters of fermenter and pipeline of external circulation loop, $\mathrm{m} ; n, D$-wheel velocity, $\mathrm{s}^{-1}$, and impeller diameter, $\mathrm{m} ; \rho, \mu-$ density, $\mathrm{kg} / \mathrm{cu}$ $\mathrm{m}$, and dynamic viscosity of the medium $\mathrm{Pa} \cdot \mathrm{s}$.

Obviously, it is impossible to compare the results, obtained by means of equations (1) and (2), directly. Thus, to compare the agitation intensity, the values of $\mathrm{Re}$ and $\mathrm{Re}^{*}$ were estimated regarding the limits of laminar-turbulent transfer for the flows in channels and apparatus with agitators respectively.

The transfer for fluid flows in channels with different geometry occurred at Retrans $\approx 2300[11,16]$. There is no such constant value for the transfer from the laminar to turbulent flow for mechanical agitation in tanks. The range of $\mathrm{Re}^{*}{ }_{\text {trans }}$ typically is obtained empirically considering the type of the agitator, its arrangement inside the fermenter and geometry of the apparatus [16-19]. On the basis of reference data [19] it was determined that the range of Reynolds number on laminar-turbulent transition for agitators with turbine impellers, lo- 
cated near the bottom, was $\operatorname{Re}^{*}$ trans $=10^{2} \ldots 10^{3}$ and developed turbulence started at $\operatorname{Re}^{*}>10^{5}$.

The estimates suggested that the range of Reynolds numbers was $\mathrm{Re}^{*}=8500$ for main (radial) flow and $\mathrm{Re}^{*}$ $\approx 1000$ for secondary (axial) flow. Thus, there was a turbulent medium flow in zone 1 (Fig. 3,a), and transitional flow in zone 2 .

In the case of agitation by circulation the range of Reynolds numbers was Recirc $=9500 \ldots 15700$ in the external loop and Referm $<600$ inside the fermenter. Consequently, the medium flow in zone 1 (Fig. 3 , $b$ ) was also turbulent, and there was a laminar flow in zone 2. It is noteworthy that the medium aeration intensified mass transfer in both cases considerably, but it was not critical for hydrodynamic schemes of the process.

Therefore, regardless of the fact that the agitation in the setups occurred by different hydraulic schemes, mass transfer processes were qualitative similar. It allowed for a conclusion that the quality of mechanical agitation and agitation by circulation were found to be similar.

The experiments should be carried out for final identification of the medium flow patterns which occurred inside fermenters. However, the results of the conducted analysis are quite enough for energy efficiency estimation of the equipment.
2. Experimental study. The experimental studies were aimed at electric power consumption determination of agitation and further estimation of the energy efficiency of the methods. Two equipment operating modes were studied: with and without aeration of the medium.

As noted above, experimental setups are the components of the fermentation complex - a working technological line for microbial pesticides production [13]. The specificities of this fermentation equipment operation in actual conditions were considered during the medium agitation modeling. First and foremost, it is related to the operating modes of the fermenter and the pump. For instance, it is envisaged that mechanical agitation occurred permanently during the whole fermentation stage, and the agitation by circulation had periodic nature. The medium aeration was also periodic. Regardless of the agitation method, the air was supplied once an hour in the amount of $2.2 l$ per $1 l$ of the medium.

It stands to mention that fermenters with the agitator and with external circulation loop, as parts of the fermentation complex, allow to obtain bacterial preparations, in particular, Planriz BT, of the similar quality.

Mechanical agitation. Power consumption for mechanical agitation in the mode without aeration was $0.036 \mathrm{~kW} \cdot \mathrm{h}$ per one hour of the cycle. In terms of the whole 24 -hour cycle, this value would be $0.87 \mathrm{~kW} \cdot \mathrm{h}$. In the mode with aeration, $0.115 \mathrm{~kW} \cdot \mathrm{h}$ was consumed

Table 1. Power consumption for agitation by circulation in the mode without aeration

\begin{tabular}{c|c|c|c|c|c|c}
\hline $\begin{array}{c}\text { Frequency } \\
\text { of blade wheel } \\
\text { rotation, rpm }\end{array}$ & $\begin{array}{c}\text { Pump } \\
\text { consumption, } \\
\text { cu dm/min }\end{array}$ & $\begin{array}{c}\text { Time } \\
\text { of complete } \\
\text { circulation, } \\
\text { min }\end{array}$ & $\begin{array}{c}\text { Power } \\
\text { consumption } \\
\text { per one } \\
\text { circulation, } \\
\mathrm{kW} \cdot \mathrm{h}\end{array}$ & $\begin{array}{c}\text { Number } \\
\text { of circulations } \\
\text { per h }\end{array}$ & $\begin{array}{c}\text { Power } \\
\text { consumption } \\
\text { per one hour of } \\
\text { the cycle, } \mathrm{kW} \cdot \mathrm{h}\end{array}$ & $\begin{array}{c}\text { Power } \\
\text { consumption } \\
\text { for one cycle, } \\
\mathrm{kW} \cdot \mathrm{h}\end{array}$ \\
\hline 1710 & 7.2 & 9.72 & 0.007 & 2 & 0.014 & 0.347 \\
2280 & 9.6 & 7.29 & 0.006 & 2 & 0.012 & 0.295 \\
2850 & 12.0 & 5.83 & 0.005 & 2 & 0.010 & 0.257 \\
\hline
\end{tabular}

Table 2. Power consumption for agitation by circulation in the mode with aeration

\begin{tabular}{c|c|c|c|c}
\hline \multirow{2}{*}{$\begin{array}{c}\text { Frequency of blade } \\
\text { wheel rotation, rpm }\end{array}$} & \multicolumn{2}{|c|}{ Power consumption per one hour of the cycle, $\mathrm{kW} \cdot \mathrm{h}$} & \multirow{2}{*}{$\begin{array}{c}\text { Power consumption } \\
\text { for one cycle, } \mathrm{kW} \cdot \mathrm{h}\end{array}$} \\
\cline { 2 - 4 } & $\begin{array}{c}\text { for the first circulation } \\
\text { (with aeration) }\end{array}$ & $\begin{array}{c}\text { for the second aeration } \\
\text { (without aeration) }\end{array}$ & total & 0.088 \\
\hline 1710 & 0.081 & 0.081 & 0.077 & 2.12 \\
2280 & 0.071 & 0.071 & 0.096 & 2.84 \\
2850 & 0.091 & 0.091 & 2.31 \\
\hline
\end{tabular}


per one hour of the cycle, $0.085 \mathrm{~kW} \cdot \mathrm{h}$ of which - during the joint work of the compressor and the agitator. Power consumption per one cycle in this mode was $2.77 \mathrm{~kW} \cdot \mathrm{h}$.

Agitation by circulation. Power consumption for agitation by circulation was determined for each pump wheel velocity. The time, required for agitation, was calculated with the consideration of the period

of complete single circulation of the whole volume of the medium using the external loop. It was determined that double circulation of the medium per each hour of the cycle was sufficient for quality agitation [2].

The results of electric power consumption estimation for agitation by circulation in the mode without medium aeration are presented in Table 1.

In the mode with medium aeration the air was supplied during the first circulation at each hour of the cycle, the second circulation was without aeration. Pressured air was supplied into the cocurrent flow of the medium, circulating in the external contour (Fig. 2). This scheme of aeration envisaged a decrease in the consumption of the pump by $15-20 \%$ on average. Therefore, the time need for complete circulation increases. However, a process duration decisive factor was the supply of estimated air volume, which conditioned the increase in the time of agitation for all the wheel velocities of the pump up to $11.5 \mathrm{~min}$ on average. The results of estimating electric power consumption for agitation by circulation in the mode with aeration are presented in Table 2.

The obtained values of power consumption were used to estimate energy efficiency of fermentation medium agitation by equation, suggested in the works $[1,2]$ :

$$
e=\frac{V}{E}
$$

where $e$ - index of energy efficiency of fermentation medium agitation, $1 /(\mathrm{kW} \cdot \mathrm{h}) ; V$ - useful effect of the process - fermentation medium volume in the setup, 1 ; $E$ - agitation power consumption per cycle, $\mathrm{kW} \cdot \mathrm{h}$.

The energy efficiency of agitation by circulation at different wheel velocities is presented in Fig. 4.

The analysis of the histogram shows that for the setup operating mode without aerationб energy efficiency increases proportionally to increasing the wheel velocity as complete recirculation of the whole volume of the medium at higher velocity required less time. Therefore, the optimal operating mode of the circulation loop, from the standpoint of efficiency usage of

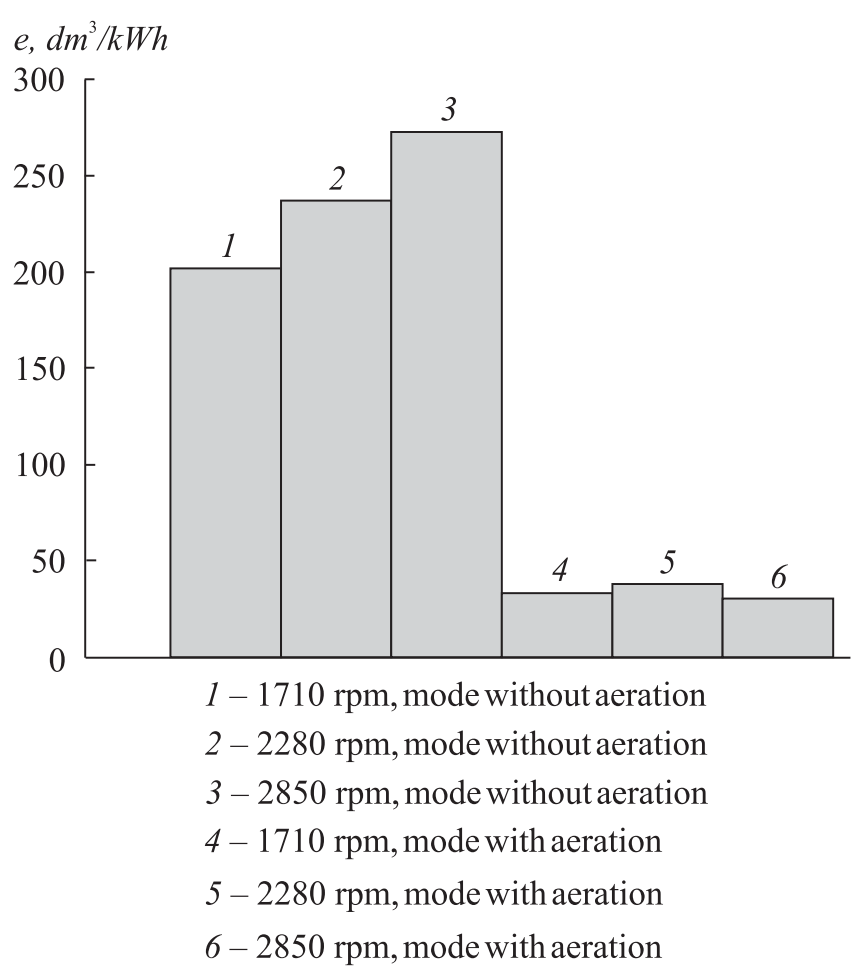

Fig. 4. The energy efficiency of agitation by circulation at different wheel velocities of the pump

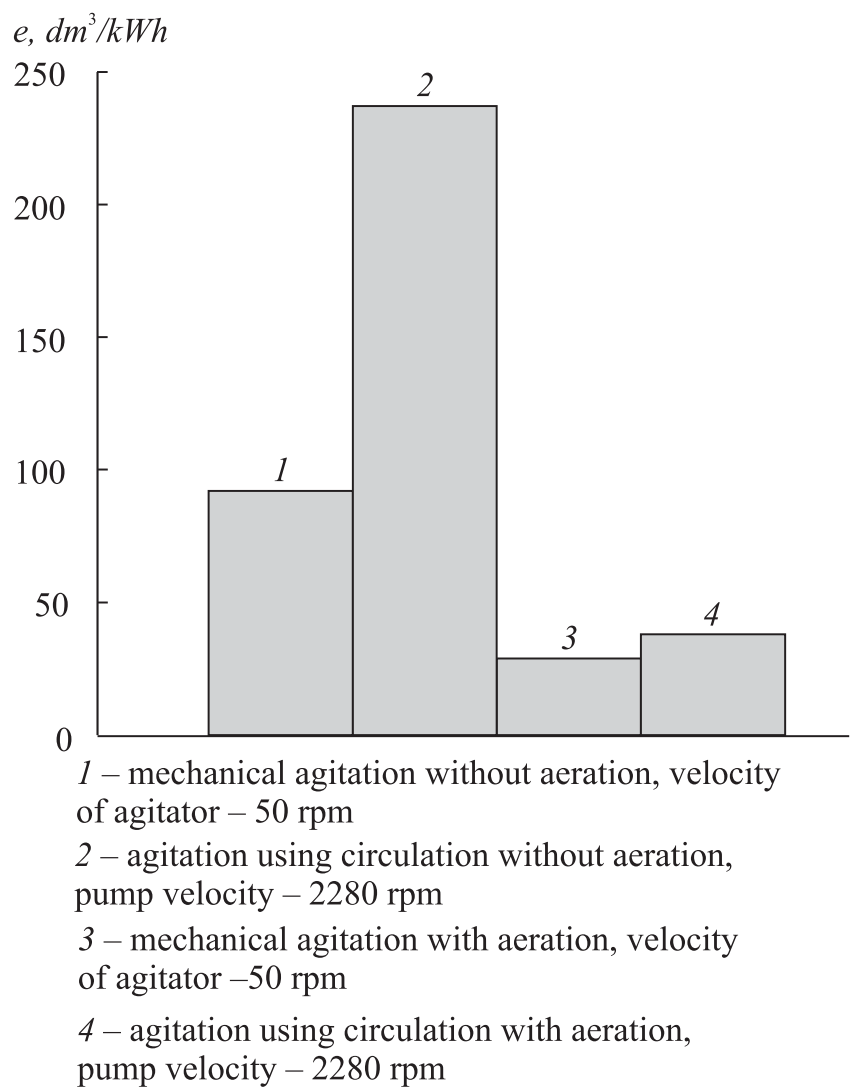

Fig. 5. The comparison of energy efficiency of different fermentation medium agitation methods 
electric energy, can be obtained at the second pump velocity $(2280 \mathrm{rpm})$ which corresponds to the maximal energy efficiency of agitation by aeration.

The comparison of energy efficiency of mechanical agitation and agitation by circulation in the optimal operating mode (Fig. 5) demonstrated that energy efficiency of agitation by circulation was 2.6 times higher compared to the mechanical method in the mode without aeration, and 1.3 times higher - with aeration.

\section{CONCLUSIONS}

The study demonstrated that the energy efficiency of fermentation medium agitation realized by means of external loop circulation exceeded the energy efficiency of the most common mechanical method 1.3...2.6 times even in the case of slow-speed agitator usage, which confirmed the results of previous analytical research [2]. Thus, the agitation by circulation is a higher priority engineering solution compared to the mechanical agitator usage at similar mass transfer characteristics. At the same time the greatest difficulties in determining the energy efficiency were conditioned not by estimations, but by substantiation of the accuracy of comparing the methods, based on different hydraulic schemes. Therefore, it is reasonable to direct further researches at improving the method of estimating the quality of agitation while applying principally different technical techniques.

The work was conducted within the implementation of the state budget program of scientific research in 2016-2020. ASR 10 Biotechnica. The author claims the absence of any conflict of interests.

\section{Дослідження енергоефективності перемішування ферментаційних середовищ при виробництві мікробіологічних препаратів для захисту рослин}

\section{В. П. Ярошевський}

Інженерно-технологічний інститут «Біотехніка» НААН, Україна

67667, Одеська обл., Біляївський р-н, смт Хлібодарське, вул. Маяцька дор., 26, Україна

$$
\text { e-mail:wladscience@gmail.com }
$$

Мета. Порівняння енергоефективності різних способів перемішування ферментаційних середовищ. Методи. Аналіз масообмінних процесів у ферментаційних апаратах при використанні різних способів перемішування. Експериментальне визначення енергозатрат на перемішування середовища при застосуванні механічної мішалки та зовнішньої циркуляційної лінії. Розрахунок показників енергоефективності. Результати. Визначено, що енергетична ефективність перемішування циркуляцією за цикл напрацювання бактеріального препа- рату Планриз БТ (Біотехніка) перевищує механічне перемішування в 1,3 рази при застосування аерації і в 2,6 рази в режимі без аерації. Висновки. Перемішування циркуляцією ферментаційного середовища зовнішнім контуром є більш енергоефективним способом, ніж механічне перемішування, навіть у разі використання малопотужної мішалки.

Ключові слова: енергоефективність, ферментаційне середовище, перемішування, інтенсивність, циркуляція, ферментер.

\section{Исследование энергоэффективности перемешивания ферментационных сред при производстве микробиологических препаратов для защиты растений}

\section{В. П. Ярошевский}

Инженерно-технологический институт «Биотехника» НААН, Украина

67667, Одесская область, Беляевский р-н, пгт Хлебодарское, ул. Маякская дор., 26, Украина e-mail:wladscience@gmail.com

Цель. Сравнение энергоэффективности разных способов перемешивания ферментационных сред. Методы. Анализ массообменных процессов в ферментационных аппаратах при использовании разных способов перемешивания. Экспериментальное определение энергозатрат на перемешивание среды при применении механической мешалки и внешней циркуляционной линии. Расчет показателей энергоэффективности. Результаты. Установлено, что энергетическая эффективность перемешивания циркуляцией за цикл наработки бактериального препарата Планриз БТ превышает механическое перемешивание в 1,3 раза при использовании аэрации и в 2,6 раза в режиме без аэрации. Выводы. Перемешивание с использованием циркуляции ферментационной среды по внешнему контуру является более энергоэффективным способом, чем механическое перемешивание, даже в случае использования маломощной мешалки.

Ключевые слова: энергоэффективность, ферментационная среда, перемешивание, интенсивность, циркуляция, ферментер.

\section{REFERENCES}

1. Yaroshevsky VP. Enhancing energy efficiency of thinwalled fermentation complexes. Inzhenerno-tekhnolohichni innovatsii u vyrobnytstvi entomolohichnykh ta mikrobiolohichnykh zasobiv zakhystu roslyn. Odesa: PE Feniks, 2017;6.5:175-89 (in Ukrainian).

2. Yaroshevsky VP, Osypenko TM. Evaluating energy efficiency of technological processes of industrial production of microbiological plant protection preparations: Materials of the International scientific practical 
conference dedicated to the 100th anniversary of NAAS of Ukraine. Biological method of plant protection: achievements and perspectives. Odesa: PE Feniks, 2018: 373-80 (in Ukrainian).

3. Bespalov IM, Hodorchuk VJa. Assessment of initial stock of soft summer wheat on parameters of quality of grain in conditions of Forest-steppe. Bull. Agric. Sci. 2017;(1):38-42. doi: 10.31073/agrovisnyk201701-07.

4. Stockill D. Energy efficiency in the process industries. A user-guide to sustainable energy efficiency. Emerson, 2014:132 p.

5. Albaek MO, Gernaey KV, Hansen MS, Stocks SM. Evaluation of the energy efficiency of enzyme fermentation by mechanistic modeling. Biotechnol Bioeng., 2012;109(4):950-61. doi: 10.1002/bit.24364.

6. Stoian D, Eshtiaghi N, Wu J, Parthasarathy R. Enhancing impeller power efficiency and solid-liquid mass transfer in an agitated vessel with dual impeller through process intensification. Ind. Eng. Chem. Res., 2017;56(24):702136. doi: 10.1021/acs.iecr.7b00435.

7. Ameur $H$. Energy efficiency of different impellers in stirred tank reactors. Energy., 2015;93(P2):1980-8. doi: 10.1016/j.energy.2015.10.084.

8. Davoody M, Abdul Raman AA, Parthasarathy R. Agitation energy efficiency in gas-solid-liquid stirred vessels operating at ultra-high solids concentrations. Chem. Eng. Res. Des., 2016;111:34-48. doi: 10.1016/j. cherd.2016.04.009.

9. Warmeling H, Behr A, Vorholt AJ. Jet loop reactors as a versatile reactor set up - intensifying catalytic reactions:
A review. Chem. Eng. Sci., 2016;149:229-48. doi: 10.1016/j.ces.2016.04.032.

10. Zaidi A, Ghosh P, Schumpe A, Deckwer WD. Xanthan production in a plunging jet reactor. Appl. Microbiol. Biotechnol., 1991;35(3):330-33. doi: 10.1007/BF00172721.

11. Blenke H. Loop reactors. Advan. Biochem. Engineer., 2005;13:121-214. doi: 10.1007/3540094687_8.

12. Sokolov VM, Yablokova MA. Equipment of microbiological industry. L.: Mashinostroenie. 1988:278 p. (in Russian).

13. Krutyakova VI. Modular type fermentation complex MFC-420. Agrarna nauka - vyrobnytstvu. 2015;(4):26.

14.Divisi D, Di Leonardo G, Zaccagna G, Crisci R. Basic statistics with Microsoft Excel: a review. J. Thorac. Dis., 2017;9(6):1734-40. doi: 10.21037/jtd.2017.05.81.

15. Tascheev $Y$. Energy efficiency: renewable and nonrenewable energy. Socio-Economic Research Bulletin. 2015;2(57):169-77.

16. Strenk F. Agitation and equipment with agitators. L.: Khimia, 1975:384 p. (in Russian).

17. Kars-Jordan F, Hiltunen P. Agitation Handbook. Stockholm, KTH Industrial Engineering and Management. 2007:90 p.

18. McDonough RJ. Agitation in fermenters and bioreactors. Handbook of downstream. 1997:357-416. doi: 10.1007/ 978-94-009-1563-3.

19. Braginsky LN, Begachev VI, Barabash VM. Agitation in liquid media: Physical fundamentals and engineering methods of calculations. L.: Khimia. 1984:336 p. (in Russian).

\section{ПРАВИЛА ДЛЯ АВТОРІВ}

У журналі «Agricultural Science and Practice» публікуються результати фундаментальних і прикладних досліджень 3 питань грунтознавства, землеробства, рослинництва, ветеринарії, тваринництва, кормовиробництва, генетики, селекції та біотехнології, агроекології, радіології, меліорації, економіки.

Друкуються статті, огляди літератури, короткі повідомлення, які раніше не видавалися.

Рукописи надсилаються на конфіденційне рецензування спеціалістам (не нижче доктора наук) відповідної галузі.

За умови позитивної рецензії з рукописом знайомиться науковий редактор - конфіденційно.

Статті надсилаються українською/російською мовою, перекладаються в редакції безкоштовно і публікуються лише англійською мовою; російською та українською - резюме. В електронній версії журналу (http://www.agrisp.com) 32014 р. розміщуються резюме, список літератури і повний текст статей англійською мовою (окрім поточного року). Кожна статTя має DOI, що сприяє коректному розповсюдженню матеріалу в мережі Інтернет.

Комплект документів, необхідних для ресстрації статті.

Електронною поштою представляються:

- лист - направлення від організації (pdf);

- договір про передачу авторських прав (pdf), оформлений і підписаний окремо кожним із співавторів, наприклад, 4 автори -

4 договори (зразок договору на сайті журналу);

- звертаємо Вашу увагу на те, що договір про передачу авторських прав набуває чинності після прийняття статті до публікації. У разі відхилення Вашої статті редколегією журналу договір автоматично втрачає силу. Підписання договору автором (авторами) означає, що він (вони) ознайомлені та згодні з умовами договору;

- рукопис (doc, docx, rtf) (прохання називати файл прізвищем першого автора статті англійською мовою, наприклад orlyk.doc); ілюстрації; таблиці.

Статті обов'язково супроводжуються українсько(російсько)-англійським словником специфічних термінів (не менше 30), використаних у статті. 